УДК 378.147:811.111

\author{
Бянь Лулу, \\ аспірантка Сумського державного \\ педагогічного університету \\ імені А. С. Макаренка
}

\title{
ПРИНЦИПИ ФОРМУВАННЯ КУЛЬТУРИ МОВЛЕННЯ СТУДЕНТІВ 3 КНР У ПРОЦЕСІ ПРОФЕСІЙНОЇ ПІДГОТОВКИ
}

У статті висвітлюються основні принципи, які покладені в основу прочесу формування культури мовлення китайських студентів у процесі професійної підготовки, серед яких: науковості, шуо передбачає розкриття причинно-наслідкових зв'язків явищ, процесів, подій, включення в засоби навчання науково-перевірених знань, які відповідають рівню розвитку сучасного мовознавства; свідомості - свідоме засвоєння студентами основних комунікативних умінь $і$ навичок та застосування їх у мовній практиці; доступності, щзо виражається в підборі доступного для студентів дидактичного матеріалу; системності $i$ послідовності, щуо дозволяє побудувати систему навчання в певному порядку: від простого до складного, від вивченого до нового; зв'язку теорії з практикою, щуо трунтується на практичній спрямованості навчання російській мові білінгвальних студентів; врахування рідної мови студентів, який базується на врахуванні відмінностей між прочесами оволодіння рідною та нерідною мовами; комунікативності, що передбачає орієнтацію на вироблення у студентів здібностей вільно використовувати отримані знання, вміння і навички в природному спілкуванні іноземною мовою.

Ключові слова: принциии, культура мовлення, білінгвальні студенти, професійна підготовка.

The article describes the main principles that underlie the process of forming the Chinese culture of broadcasting in the process of professional training, among which: scientific, which involves disclosing the causal relationships of phenomena, processes, events, inclusion in the means of teaching scientifically proven knowledge, which correspond to the level of development of modern linguistics.

The principle of scientific knowledge requires constant monitoring of the latest scientific information, systematization of it and within the framework of the working program on specialist discipline, familiarizing students with it, giving them the task of independently processing new scientific sources; Consciousness is a conscious assimilation of students' basic communicative skills and their application in language practice. A conscious approach of 
Chinese students to the phenomena of language is an understanding of the logic of definitions, characteristics of linguistic concepts; comprehension of connections between semantics and means of its expression, etc .; accessibility, which involves the availability of the investigated material, meaningful technology of its presentation, the need for special training of the teacher; systematic and consistent, which allows to build a system of learning in a certain order: from simple to complex, from the learned to the new one. At the same time, the article deals with the question of both the system and the sequence of filing of the program material, as well as the system of selection of rational methodical techniques for its study; connection theory with practice, recognized as the most important principle of learning, because it is based on the practical orientation of teaching the Russian language bilingual students, the development of their communicative skills and skills, the formation of a culture of speech; taking into account the native language of students, which is based on taking into account the differences between the processes of mastering the native and non-native languages; communicative, which envisages the orientation on the ability of students to freely use the acquired knowledge, skills and abilities in natural communication in a foreign language.

Key words: principles, speech culture, bilingual students, professional training.

Основне завдання сучасної професійної освіти полягає у формуванні та розвитку особистості студента, створенні умов для його самореалізації не тільки у вузькопрофесійній сфері, але i в самих різних сферах суспільного життя. Вища школа націлена на формування різнобічної, моральної, активної особистості, здатної в умовах багатонаціонального середовища до самореалізації, до міжкультурного спілкування. Вирішення цієї проблеми необхідно привести у відповідність 3 новою освітньою ситуацією, тенденціями методичної науки. У зв'язку з цим, великого значення набуває знання основних законів російської літературної мови, що забезпечують ясну, дохідливу передачу думки і почуття в процесі спілкування людей один з одним.

Розглядаючи питання формування культури російської мови, не можна не відзначити домінуючу роль педагогічних закладів, в яких тільки починає формуватися традиція навчання культурі мовного спілкування. Необхідність володіння мовною культурою при цьому пояснюється роллю мови як основного інструменту спілкування; майбутній учитель працює «в зоні підвищеної мовної відповідальності»; мова викладача - це і засіб навчання, і зразок для наслідування; спілкування виступає для педагога як мета, і як зміст.

Пошук ефективних шляхів комунікативної підготовки китайських студентів у вітчизняних педагогічних вузах стає соціально необхідним у 
зв'язку з тим, що це питання недостатньо вивчене в теорії і практиці навчання студентів-білінгвів i не отримало достатнього теоретичного висвітлення і практичного втілення.

Незважаючи на те, що проблема формування культури мовлення у студентів досліджується достатньо широко (Є. Бистрова, Т. Донська, Є. Верещагін, С. Клюєв, І. Зимня, В. Костомаров, Н. Шанський та ін.), вона не має методичного рішення, та залишається актуальною в білінгвальній аудиторії. На наш погляд, така ситуація пояснюється тим, що в процесі викладання більша увага приділяється формуванню теоретичних знань про культуру мовлення, внаслідок чого вміння користуватися різноманітними мовними засобами у студентів формується не повноцінно.

Методологічною і лінгвістичною основою дослідження $є$ праці в області психології спілкування (Л. Виготський, І. Зимня, О. О. Леонтьєв, О. М. Леонтьєв та ін.); теоретичні положення дидактики представлені в роботах Д. Ізаренкова, В. Костомарова, I. Лернера, О. Мітрофанової, С. Шатілова та ін.; дослідження в галузі культури мови i мовного спілкування представлені у працях А. Акішина, Г. Васильєвої, Л. Введенського, О. Гойхмана, Б. Головіна, Л. Клобукова, С. Клюєва, О. Мотовилової, Н. Іпполітова та ін.

Мета статті - висвітлити основоположні принципи, які покладені в основу процесу формування культури мовлення студентів з КНР у процесі професійної підготовки.

Ефективність формування культури мовлення китайських студентів у процесі професійної підготовки у вітчизняних вузах безпосередньо залежить від використання певного кола педагогічних принципів у навчально-виховному процесі.

Ми погоджуємося 3 думкою, що принцип (від лат. principium початок, основа) - це основне вихідне положення будь-якої теорії, вчення, науки, світогляду, теоретичної програми; внутрішнє переконання людини, що визначає іiі ставлення до дійсності, норми поведінки в діяльності [5].

В українському педагогічному словнику зазначається, що педагогічні принципи - це вагомі положення, які відображають загальні закономірності процесу навчання та виховання і визначають вимоги до змісту, організації i методів навчально-виховного впливу. Вони є узагальненою системою вимог, які охоплюють усі аспекти зазначеного процесу та відображають його результати [3]. Таким чином, під принципами ми розуміємо систему основних вимог до навчання $i$ виховання, дотримання яких дає змогу ефективно вирішувати проблему формування культури мовлення китайських студентів у прочесі професійної підготовки.

Розглянемо найбільш важливі дидактичні принципи, що є вихідними положеннями в розробленій нами методичній системі: науковості, 
свідомості, доступності, системності, послідовності, зв'язку теорії 3 практикою, виховуючого навчання, наочності, врахування рідної мови студентів, нормативно-стилістичний, а також принципи комунікативного навчання спілкуванню (мовномисленнєвої активності, індивідуалізації, функціональності, системності, ситуативності, новизни).

Зазначимо, щуо принции науковості вимагає, щоб зміст освіти вищої школи відповідав досягненням науки у відповідній галузі знань. Студенти мають засвоювати достовірні, науково обгрунтовані факти, явища, процеси, розуміти сутність науково обгрунтованих законів, особливості розвитку і становлення наукових відкриттів, володіти методами наукових досліджень, знайомитися з різними напрямами наукових пошуків у тій чи іншій галузі знань 3 перспективами розвитку наукових гіпотез. Необхідною умовою принципу науковості $\epsilon$ формування пізнавальних інтересів у студентів, їх залучення до різних форм наукових пошуків, стимулювання інтересу до таких видів діяльності.

Щодо проблеми нашого дослідження, принцип науковості передбачає опору на дані сучасного мовознавства, при цьому важливо встановити лінгвістичні передумови, на яких будуть базуватися розроблені нами зміст і система навчання. Для цього необхідно усвідомлення студентами співвідношення понять компетентність - компетентнісний підхід - компетенція 3 урахуванням білінгвальних особливостей. Реалізація принципу науковості в процесі навчання російської мови, за справедливим твердженням М. Успенського [7], настільки специфічна, що його правомірно вважати не тільки дидактичним, а й лінгвометодичним.

Працюючи над реалізацією вимог принципу науковості, не можна обмежуватися лише орієнтацією на зміст підручників i навчальних посібників. В умовах дії наукового «вибуху», що характерно для розвитку науки в другій половині XX і початку XXI ст., обсяг інформації у всіх сферах науки подвоюється в середньому через 7-8 років, а в окремих галузях - значно швидше. Тому 3 погляду вимог принципу науковості викладачеві необхідно постійно стежити за новітньою науковою інформацією, систематизувати іiі і в рамках робочої програми 3 конкретної дисципліни знайомити 3 нею студентів, давати їм завдання самостійно опрацьовувати нові наукові джерела. Так, з урахуванням того, що в останні десятиліття в методиці використовуються такі теоретичні положення сучасної лінгвістики, як розмежування мови і мовлення, мовної та мовленнєвої системності, актуальним стало питання про необхідність роботи над зв'язним текстом, сприйняттям і породженням зв'язного висловлювання, адже саме в тексті засоби стають комунікативно значимими, комунікативно зумовленими, об'єднаними в певну систему, в якій кожна 3 них найбільш повно проявляє свої сутнісні ознаки і виявляє нові, текстоутворювальні функції [4, с. 9]. 
Урахування принципу свідомості передбачає свідоме засвоєння студентами основних комунікативних умінь і навичок та застосування їх у мовній практиці. Свідомим підходом у китайських студентів до явищ мови можна вважати розуміння логіки визначень, характеристик лінгвістичних понять; осмислення зв'язків між семантикою і засобами ії вираження тощо. Отже, практичне застосування цього принципу в експериментальному навчанні ми бачимо в детальному розгляді студентами мовних норм i реалізації їх у мовленні. Погоджуючись з М. Успенським, свідомий підхід до вивчення мовних явищ ми пов'язуємо 3 формуванням у студентів лінгвістичного мислення [7, с. 37].

Реалізація актуального дидактичного принципу доступності в студентській аудиторії передбачає доступність досліджуваного матеріалу, осмислену технологію його викладення, необхідність спеціальної підготовки викладача.

Дотримання принципу системності $i$ послідовності дозволяє побудувати систему навчання в певному порядку: від простого до складного, від вивченого до нового. При цьому важливо розглядати питання як про систему і послідовність подачі програмного матеріалу, так i про систему відбору раціональних методичних прийомів для його вивчення. Системні подібності мов вимагають від викладача використовувати порівняння, аналогії, протиставлення.

Уміння знайти в раніше вивченому те, що допоможе зрозуміти нове - значить одночасно з принципом системності реалізувати принцип наступності. Принцип наступності, який передбачає послідовність у викладенні навчального матеріалу, формування нових знань 3 опорою на раніше набуті знання, вміння та навички, пов'язаний 3 принципом nерспективності в навчальному процесі. При необхідності викладач повідомляє на своїх заняттях інформацію, яку відповідно до навчального плану та програми студенти повинні отримати згодом.

Принцип зв'язку теорії з практикою визнається нами найважливішим принципом навчання, тому що грунтується на практичній спрямованості навчання російській мові білінгвальних студентів, розвитку ïх комунікативних умінь і навичок, формування культури мовлення.

Принцип виховуючого навчання на заняттях 3 російської мови проявляється в тісному зв'язку формування знань, умінь і навичок 3 формуванням світогляду студентів, їх переконань, поглядів, а також естетичного смаку. В експериментальному дослідженні даний принцип розглядається нами в навчальний і позанавчальний час.

Реалізація принципу наочності при навчанні культурі російської мови іноземних студентів залежить, на наш погляд, від вдалого підбору мовного матеріалу для спостереження, аналізу і тренування мовних зразків, текстів. Уміло підібраний текстовий матеріал являє собою зразок 
правильного зв'язного мовлення.

3 урахуванням доцільності використовувалися такі засоби позапрограмного виховного впливу, як позааудиторні бесіди зі студентами, дискусії, образні тексти виховного характеру, інформація яких доповнювалася новими відомостями, судженнями, проблемними ситуаціями.

У своєму дослідженні ми також спиралися на принцип врахування рiдної мови студентів, який забезпечувався за допомогою використання даних порівняльного аналізу. Використання цього принципу забезпечувало свідомість і ефективність навчання, підвищувало науково-методичний рівень викладання, грунтуючись, при цьому, на психологічних i дидактичних засадах навчання нерідній мові. Ми спиралися на аналіз відмінностей між процесами оволодіння рідною та нерідною мовами, який запропонований Л. Виготським: «...іх розділяє елемент усвідомленості i навмисності, характерний для оволодіння іноземною мовою, i, навпаки, повністю відсутній при оволодінні рідною мовою» і далі: у процесі оволодіння нерідною мовою «раніше розвиваються вищі, складні властивості мови, пов'язані з усвідомленням і навмисністю, і тільки пізніше виникають більш елементарні властивості, пов'язані зі спонтанним, вільним користуванням мовою» [2, с. 191]. Згідно з цим, нами здійснювався відбір мовного матеріалу і теоретичних відомостей, підбір вправ і текстового матеріалу з урахуванням двомовної аудиторії, навчання ïx мовного спілкування російською мовою. При цьому ми намагалися використовувати взаємодію систем рідної та російської мов: в одних випадках відвести студента від лексико-граматичних категорій рідної мови, в інших, - закріпити в його свідомості мовні асоціації $[9$, с. 33]. Слідом за Т. Кудрявцевою, вважаємо за доцільне виділення трьох аспектів навчання спілкуванню: навчання мовним засобам; навчання мовним навичкам і вмінням; навчання комунікативним навичкам і вмінням, тобто навчання власне спілкування [8, с. 41].

У дослідженні ми спиралися на нормативно-стилістичний принцип у формуванні культури мовлення. Опора на нього сприяла виробленню у студентів-білінгвів критичного, вдумливого, вимогливого ставлення до відбору мовних засобів, забезпечуючи правильну і емоційно-виразну мову.

Згідно з принципом мовномисленнєвої активності процес навчання організовується таким чином, щоб студенти постійно були залучені в процес спілкування. Даний принцип передбачає, що змістовною основою комунікативного навчання $\epsilon$ проблемність. Для активізації розумової діяльності студентів і появи у них потреби висловлюватися необхідно здійснити відбір проблем і проблемних ситуацій, які викликають у них інтерес.

Реалізація принципу індивідуалізачії вимагає диференційованого навчання відповідно до вікових, психологічних, національних та інших особливостей студентів. 
У викладанні російської мови у вищій школі особливо важливе значення має використання пов'язаних між собою лінгвометодичних принципів функиіональності і системності. Зазначимо, що кожна одиниця мови виконує ту чи іншу функцію або ряд функцій в мові та мовленні, i студентам необхідно показати роль цих функцій в ході навчального процесу.

У викладанні російської мови принцип функиіональності проявляється по-різному: при характеристиці загальних функцій мови; по відношенню до окремих аспектів російської мови (призначення, роль мовної одиниці у в мові) [1, с. 506]; у вираженні граматичного значення i форми; при характеристиці функціональних стилів російської мови.

Вираженням принципу системності правомірно вважати як виявлення типових ознак мовної системи у всіх аспектах мови, так i нормативну реалізацію цих ознак.

Принцип ситуативності розглядається у нашому дослідженні як основний лінгводидактичний принцип в комунікативно-орієнтованому навчанні, тому що саме від ситуації спілкування багато в чому залежить варіативність мовних висловлювань. Згідно з цим принципом, одиницею організації процесу навчання іншомовного спілкування визнається ситуація, яка розуміється як система взаємовідносин студентів. Реалізація принципу ситуативності передбачає створення на заняттях ситуацій, які в значній мірі наближені до умов природної комунікації, що відтворюють комунікативну реальність.

Для успішного комунікативного навчання необхідна опора на принцип новизни. Згідно з цим принципом, новизна повинна проявлятися в змісті матеріалу, в умовах і прийомах навчання, в формах організації навчального процесу тощо. Реалізація принципу новизни сприяє підтримці інтересу до навчання, формування мовних навичок, здатних до переносу, розвитку продуктивності і динамічності мовних умінь.

Принцип комунікативності передбачає орієнтацію на вироблення у студентів здібностей вільно використовувати отримані знання, вміння $\mathrm{i}$ навички в природному спілкуванні іноземною мовою. Таким чином, методичний зміст принципу комунікативності полягає «в подібності процесу навчання процесу комунікації» [6, с. 138]. Даний принцип підпорядковує собі всі сторони процесу навчання: співвідношення знань 3 навичками i вміннями; вибір методів, прийомів навчання і способів презентації навчального матеріалу, визначення змісту навчального процесу і т.п.

Реалізація принципу комунікативності полягає в уподібненні процесу навчання процесу реальної комунікації, що передбачає: комунікаційну спрямованість занять, тобто організацію постійної мовної практики; взаємозв'язок теоретичних і практичних знань; активізацію мисленнєвої та мовної діяльності за допомогою навчально-комунікативних 
мовних ситуацій; використання спеціального «комунікативно-цінного» (О. Митрофанова) текстового матеріалу; формування певних професійних методичних умінь.

Таким чином, нами визначено основоположні принципи, реалізація яких забезпечить ефективність формування культури мовлення студентів 3 КНР у процесі професійної підготовки, а саме: науковості, свідомості, доступності, системності, послідовності, зв'язку теорії 3 практикою, виховуючого навчання, наочності, врахування рідної мови студентів, нормативно-стилістичний, а також принципи комунікативного навчання спілкуванню (мовномисленнєвої активності, індивідуалізації, функціональності, системності, ситуативності, новизни).

Проведене дослідження не вичерпує всіх питань процесу формування культури мовлення студентів з КНР у процесі професійної підготовки. Воно окреслює перспективу для подальшого вивчення питання формування мовних, мовленнєвих, комунікативних компетенцій студентів-білінгвів та технологій їх розвитку в умовах сучасного навчання у вищій школі.

\section{СПИСОК ВИКОРИСТАНИХ ДЖЕРЕЛ}

1. Апресян Ю. Д. Образ человека по данным языка / Ю. Д. Апресян // Избранные труды. Т. 2 / Ю. Д. Апресян. - М., 1995. - С. 506.

2. Выготский Л. С. Мышление и речь : избранные психологические исследования / Л. С. Выготский. - М., 1965. - 519 с.

3. Гончаренко С. У. Український педагогічний словник / Семен Устимович Гончаренко. - К. : Либідь, 1997. - С. 187.

4. Ипполитова Н.А. Текст в системе изучения русского языка / Н. А. Ипполитова. - М., 1992. - 126 с.

5. Никитина Е.Л. Педагогические принципы взаимодействия семьи и школы / Е. Л. Никитина // Личность, семья и общество: вопросы педагогики и психологии : сб. ст. по матер. XXXVI междунар. науч.практ. конф. № 1(36). - Новосибирск : СибАК, 2014.

6. Пассов Е.И. Основы коммуникативной методики обучения иноязычному общению / Е. И. Пассов. - М., 1989. - 276 с.

7. Успенский М. Б. Курс современного русского языка в педагогическом вузе : учебное пособие / М.Б. Успенский. - М. : Издательство Московского психолого-социального института; Воронеж : Изд-во НПО «МОДЭК», 2004. - 192 с.

8. Что значит знать язык и владеть им / Н. М.Шанский, И. Л. Резниченко, Т. С. Кудрявцева и др. ; под ред. Н. М. Шанского. Л. : Просвещение, 1989. - 192 с.

9. Шакирова Л. 3. Методика преподавания русского языка в национальной школе : учебное пособие для учащихся национальных групп педагогических училищ / Л. З. Шакирова. - Л., Просвещение, 1990. - C. 33. 